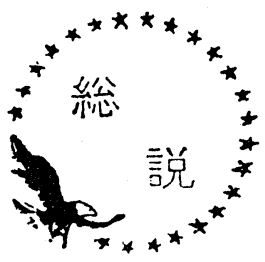

水質污濁の测定

——昭和 46 年 3 月 13 日受理——

公害資源研究所 梅 崎 芳 美

\section{1. は じめに}

人口の都市集中, 産業活動の拡大, その多様化が進 行するにつれて, 各種の公害問題が多く発生し, 水質 污濁もまたその例外ではありえない。

水質污濁が深刻化するにつれて, 水域污濁の実態調 查, 放流水の水質管理, 監視, あるいは水道, 農業用 水などの利水水質の管理など水質測定への要求は量に おいて急増するとともに, 新しい污濁質の測定あるい は超微量成分の測定など質の面においても厳しさを加 えてきている。

これに対応して新しい測定機器, モニタ一計器など のハードウェアーの開発, 改良に多大の努力が重ねら れ，この数年間の質的向上のあとは著しいものがあ る。同時にこれらの正しい運用, あるいは新しい分析 原理, 方法の開発といつたソフトウェアーの重要性に 対する認識を強調しなければならない。すなわち, 従 来ともすれば分析, 測定の機器化, 自動化の華やかな 面が先行し, その基礎, 背景としての方法論の分野が 過少に評価される傾向があつた。たしかに, 水質測定 の理想的な形態は試料の採取, 調製, 前処理 (センサ 一方式では試料直接), 測定, 計算, 結果表示, 統計 処理といつた一連の作業の完全自動化であろう。しか し, 残念ながら現在この域に達している測定項目はご く限られたものだけであり, 大部分は測定以前に多く の問題を抱えている。つまり, 機器分析, 自動分析は 水質測定の手段としてきわめて重要であるが，少なく とも現時点においては, その性能は完全ではなく, 限 界を心得た運用が必要であり, その基礎として豊富な 化学的知識が要求されることを忘れてはならない。

以上の点を考慮しながら水質污濁測定法およびこれ に付随する問題の現状と将来について述べる。

\section{2. 測定項目と水質基準}

水質污濁成分は質, 量を考慮するとほとんど無数に 存在することになる。しかし, 水質測定に関する各種 公定法に取上げられている污濁質の種類は大体共通し
ており，たとえば現在改正作業中の J I S K 01021971 工場排水試験方法に予定されている約 60 の測定 項目をその公約数とみてよいであろう。その内訳は

金属: $\mathrm{Cu}, \mathrm{Zn}, \mathrm{Hg}$ (全, アルキル), $\mathrm{Cd}, \mathrm{Pb}$ など 20 数種,

非金属: $\mathrm{Cl}^{-}, \mathrm{SO}_{4}^{2-}, \mathrm{CN}^{-}, \mathrm{NO}_{2}^{-}, \mathrm{NO}_{3}^{-}$など 10 数 種,

その他: $\mathrm{pH}, \mathrm{BOD}, \mathrm{COD}, n$-ヘキサン抽出物質 (油分), 懸濁物 (SS), 溶存酸素, フェノ一 ルなど 20 数種

となつている。

一方, 各種水質基準についてみると規制項目はさら に少なくなつている。たとえば, 公害対策基本法に基 ゔいて 1970 年 4 月 21 日に閣議決定された “生活環境 （広義）に係る環境基準”では,

$\mathrm{pH}, \mathrm{BOD}$ (生物化学的酸素要求量), $\mathrm{COD}$ (化学 的酸素要求量), SS (懸濁物質), DO (溶存酸素), 大腸菌群数

の基準值をまた同じく“人の健康に係る環境基準” では

シアン, アルキル水銀, 全水銀, 有機りん, $\mathrm{Cd}$, $\mathrm{Pb}, \mathrm{Cr}(\mathrm{VI}), \mathrm{As}$

の基準值を定めている。

このほか, 旧水質保全法に基づいて定められた指定 水域 (1971年 1 月現在64水域) の規制水質項目，ある いは自治体条令の定める水質項目として多くみられる のは上記のほかに

$\mathrm{Cu}, \mathrm{Mn}, \mathrm{Zn}$, フェノール, 油分 ( $n$-ヘキサン抽 出物質), アンモニア態窒素, $\mathrm{F}^{-}$ などである。

\section{3. 試 料 採 取}

水質測定の出発点として, 試料採取の意義はきわめ て大きい。しかし，目的とする水質を正しく代表する 試料を採取することは至難の業である。したがつて, われわれに要求されるのはいかにして少しでも真の姿 
に近い代表試料を得るかということである。

水質調查, 試験の目的によつて試料採取における問 題点は当然異なつてくる。この目的といらのは多様で あるが大別して 時間的調查と空間的調查に 分類でき る。前者は排水口, 利水点をはじめある一定地点にお ける水質を継続的に測定し, 平均水質, 変動などを把 握しょらとするものである。後者は一つの水系, ある いは水域における水質, とくに污濁質の挙動を解析し ようとするもので, 系に拈ける定常状態の確立——污 染源の正常操業, 平水時など人工, 自然の両面での ——した時点を選んで全域における一せい試料採取を 実施する。これは，いわ時の流れの切断点を見る方 法ともいえよう。この方式では系全体について污濁質 の挙動は明白に提示されるが，これはあくまで一時点 の姿にすぎないので, この種の調查を年に数回, 数年 にわたつて実施すれば，正しい水系の姿をみることが できる。このよらな長期広域水質調查は地球化学, あ るいは基淮設定などを目的とする場合に行なわれてい る。

\section{3-1 定点での試料採取}

定点における水質を論ずる場合, 平均水質の把握が 重要であり，いかにして水質変動の影響を平均化する かが問題となる。

連続操業の排水で大きい処理施設を経由して放流さ れる場合は水質変動は少ない。この場合は事故, 溢 流, その他偶発的な水質変動を除外すれば, 平均水質 の把握は比較的容易である。

非連続操業で, しかも処理施設 の容量が 小さい場 合, 非緩衝の排水は著しい水質変動を生じやすい。こ の場合, 予想される変動の程度に応じて, 作業時間中

（8２4時間）一定間隔で採水し，個別に，または一 つの試料として分析供する方法がとられる。採水間 隔は短いほど, 水質変動の影響が消去されるが, これ を人手で行なうのは容易ではないので自動採水器を用 いるとよい。自動採水器は流水中に水車を浸して, 翼 の回転により少量ずつをサンプリングする方式, 一定 時ごとに小型定量ポンプを作動させて採水する方式が その主なものである。

3 -2 水系に扮ける試料採取

1) 採水地点

一般的な採水地点決定の基準を下に示す。

採水の便利なところ 橋, 渡船などがあつて容易 に流心に接近できる地点を選ぶ。とくに冬期, 積雪地 帯ではこれはとくに重要である。

均一な水質が期待できるところ採水を河川断面
の 1 点で代表するためには，混合状態がよく，均一な 水質であることが必要である。本, 支流の合流直後, とくに流速の緩やかな中流以降では混合状態が悪いの で原則として採水しない。水系の途中にあるダム，あ るいは河口近くの感潮域では本質的に均一水質は期待 できないので, 要すれば横断線上に数点, 垂直にも数 点, いわゆる立体採水を行なら。

そのほか, 採水上の重要地点としては排水口, 用水 取入口，流量観測地点などを考慮する。

2) 採水部位

水路, 小河川川幅が狭く, 混合もよいので採水 や流量測定に都合のよい地点を選べばよい。

河川混合状態のよい地点で, 断面上の最大流速 部位，流心，またはその表流水を採水する。

湖沼, 貯水池, 感潮河川など 深度によつて水質 が変動するので層別に採水する。

3) 採水方法

採水は試料容器を直接, 水中に浸して行ならのが簡 単である。水路, 小河川, 舟による採水ではこの方法 を用いる。ビーカー, プラスチックのひしやくなども これに準じて使用する。

高い位置からの採水にはロープを付けたポリバケツ を多く使用する。ロープの付着物によつて水が污染さ れやすいのでとくに注意する。場合によつては海釣り 用の丈夫なリールも活用できる。

深度別, 層別の採水认は通常, 北原式絶縁採水器が 便利である。これは深度数 $10 \mathrm{~m}$ までは有效に使用でき る。そのほか, 湖沼用にほサイホン式, ポンプ式など の採水法が, 海域では転倒採水器とルーカス(撩上機) の併用, あるいはエンジン冷却水を採水するなどの方 法がとられている。

採水量は測定成分, 濃度, 方法などによつて変動す るので一律に規定できないが, 大体の目安はJIS K 0101 工業用水試験方法に示されている。

以上は均一に溶解, あるいは分散した成分について の採水方法であるが，不均一試料の場合も考えておか なければならない。n-ヘキ专ン抽出物質 (いわゆる 油分）定量用の採水では，1）落下する水，2）水路,

3）開水域，4）表層のそれぞれについて採水方法が提 案されている。

\section{$3-3$ 試料容器}

容器はポリエチレン製, または無色の硬質ガラス製 のものを用いる。せんは密閉できる必要があるが, ゴ ム,コルクせんは污染の伦険が大きいので原則として 使用しない。 
容器はあらかじめ酸でじゅうぶしに洗浄したものを 用い, 採水時, 現地の水で数回ゆすいだ後, 使用す る。

重金属類, とくに環境試料の採水においては, 一般 にごく微量の定量を要求されるので注意を要する。す なわち, 環境試料の採水では常に新しいポリエチレン びんの使用が望ましい。また，古くなつたポリエチレ ンびんでは酸素, 光, 熱などの作用によつて遊離のカ ルボキシル基, カルボニル基などを生じ吸着性が増大 するといわれる。

一般にポリエチレン中には製法，ロットによつて異 なるが， $\mathrm{Al}, \mathrm{Ca}, \mathrm{Cr}, \mathrm{Cu}, \mathrm{Fe}, \mathrm{Mg}, \mathrm{Ti}$ などが含ま れている。通常, その量は ppm 以下であり, しかむ 実際に溶出するものはその一部であるからほとんど問 題となることはない。しかし，ppbレベルを扱うとき は, 容器だけでなく, 試薬についてもじゅうぶんに注 意しなければならない。

微量ほら素の定量において硬質ガラスの使用が，ま たアルカリ金属の定量に㧤いて新しいガラス容器が適 当でないことはもちろんである。このほか, 鉄, 亜鉛 などのありふれた元素の微量を定量するときは, とく に污染に注意を要する。

\section{3-4 試料の保存}

採取した試料はできるだけ速やかに分析することが 望ましいが，多数の試料を扱らときは分析に着手する までにかなりの日時を要することになる。この間にお ける水質の変化を防止, あるいは最小纪留めるために 測定成分に応じていろいろの処理が行なわれる。

1）重金属

溶存成分の加水分解, 吸着などによる水質変化を防 止するために適量の酸添加を行なら。通常, 試料 $1 l$ につき塩酸 $10 \mathrm{~m} l$ を添加する。ただし, 微量水銀の定 量においては塩酸に含まれるブランクが影響するので 超特級 (SSG) 塩酸を用いるか, 精製するなどの配慮 が必要である。

ここで重金属類の挙動に関して重要な意味をもつ溶 存量と全量の考元方を述べて抗こう。JIS M0202 坑水・廃水試験方法では重金属の定量表示をこの両者 で行ならことを規定している。この種の水では重金属 を含む浮遊物が土壇污染の要因となるので単に溶存成 分のみを定量することは問題である。同時に, 溶存量 と全量の比, 溶存比の追跡から処理過程における固液 分離, 流下における加水分解の進行, 底質混入などの 状況を明らかにすることができる。

溶存量定量用の試料は, 採水後なるべく短時間のら
ちにろ過し，ろ液に酸添加して保存する。全量定量用 の試料は採水後, 所定の酸処理を行ない, 定量時には ビゅらぶんに酸処理して可溶成分を浸出, これを定量 に供する。

同様の意味において，銅の定量值表示に提案された $\mathrm{pH} 1$ 可溶銅の取扱いも実際に則した方法である。

2) シアン, イオウイオン

酸性 中性では揮散, 分解しやすいので, 採水直後 に水酸化ナトリウム溶液を加え $\mathrm{pH}$ 12以上とし， 5～ $10^{\circ} \mathrm{C}$ で保存する。後者はカドミウムによる固定も行 なわれている。

3) よう素, 臭素イオン

酸性側で不安定なので, 水酸化ナトリウムあるいは 炭酸ナトリウムで $\mathrm{pH}$ 10以上にする。

4）アンモニウム, 亜硝酸イオン, 有機態窒素

アルカリ側では不安定であり, 微生物の作用をうけ 易いので酸を加えて $\mathrm{pH} 2$ 以下にする。

5) フェノール類

リン酸を加えて $\mathrm{pH}$ を 4 以下とし，試料 $1 l$ 亿つき 硫酸銅 $1 \mathrm{~g}$ を加え， $5 \sim 10^{\circ} \mathrm{C}$ で保存する。24時間以 内に試験する。

6) nーヘキサン抽出物質

塩酸を加えて $\mathrm{pH} 4$ 以下にする。

7) $\mathrm{COD}, \mathrm{BOD}$

採水後, 速やかに試験する。低温にすればある程度 変質を抑制できるが完全ではない。これは微生物によ る影響が大きいので, 同様の問題があるアンモニア, S S の場合と同じく水銀塩の添加が有効である。もち ろん，BODの場合はこの操作は適用できない。

\section{4. 水 質 測 定}

水質測定法の詳細を, たとえば J I S 工場排水試験 方法に示された約60の項目について説明することは紙 数の関係から不可能でもあり, かえつて興味を殺ぐこ とにもなりかねないので, 比較的問題が多い項目につ いて重点的に求べることにする。

\section{4-1 重金属}

“重金属”とは軽金属に対応する語で, 常識的には 比重 5 以上の金属を指している。ただし, 公害問題に 関連していわれる場合は, 水銀, カドミウム, 鉛, ひ 素など人の健康に重大な影響をおよぼす特定の重金属 を指すことが多い。

これら重金属の分析に当たつては, 水質基準值を参 考にして適切な分析方法を選択し, さらに要すれば濃 縮分離などの前処理を行なわなければならない。表 1 


\section{表 1-1 各種水質基準抜すい}

単位 $(\mathrm{ppm})$

\begin{tabular}{|c|c|c|c|c|c|c|c|c|}
\hline 目 & $\begin{array}{l}\text { 人の健康 } \\
\text { に係る水 } \\
\text { 質基準 }\end{array}$ & $\begin{array}{l}\text { 水質保全 } \\
\text { 法告示排 } \\
\text { 出基準 }\end{array}$ & $\begin{array}{l}\text { 金属鉱山 } \\
\text { 保安規則 } \\
\text { 排出基準 }\end{array}$ & $\begin{array}{l}\text { 水䆃法 } \\
\text { 水頃基準 }\end{array}$ & $\begin{array}{l}\text { WHO飲 } \\
\text { 料水水質 } \\
\text { 基準 }\end{array}$ & $\begin{array}{l}\text { 水産資源 } \\
\text { 保護協会 } \\
\text { 水産用水 } \\
\text { 基淮 }\end{array}$ & $\begin{array}{l}\text { 海 水 中 } \\
\text { Gooldberg }\end{array}$ & $\begin{array}{l}\text { 地 殼 中 } \\
\text { Taylor }\end{array}$ \\
\hline & 45. 4. 21 & 45. 9.9 & 45. 6.10 & 41. 5. 6 & 1963 & 1965 & 1963 & 1964 \\
\hline ア ン) & 不検出 & 1 & 1 & 不検出 & 0.2 & 0.01 & & \\
\hline (アルキル) & 不検出 & 不検出 & 不検出 & - & - & - & & \\
\hline （全） & 不検出* & 不検出 & 0.01 & 不検出 & - & 0.004 & 0.00003 & 0.08 \\
\hline 機 リ & 不検出 & 1 & - & 不検出 & - & - & & \\
\hline & 0.01 & 0.1 & 0.1 & $(0.01)$ & 0.01 & 0.03 & 0.00011 & 0.2 \\
\hline & 0.1 & 1 & 1 & 0.1 & 0.05 & 0.1 & 0.00003 & 12.5 \\
\hline (V1) & 0.05 & 0.5 & 0.5 & 0.05 & 0.05 & - & & \\
\hline & 0.05 & 0.5 & 0.5 & 0.05 & 0.05 & - & 0.003 & \\
\hline & - & - & $3^{* *}$ & 1.0 & 1.0 & 0.01 & 0.003 & 55 \\
\hline & - & - & $5^{* *}$ & 1.0 & 5.0 & 0.1 & 0.01 & 70 \\
\hline （全） & - & - & $2^{* *}$ & - & - & 1.0 & 0.00005 & 100 \\
\hline & - & - & - & 0.3 & 0.1 & 1.0 & 0.002 & 950 \\
\hline & - & - & - & 0.3 & 0.3 & 1.0 & 0.01 & 56300 \\
\hline
\end{tabular}

* 45. 5. 29 追加

**省令 46 号 (45.8.7) の運用

\section{表 1 - 2 生活環境に係る環境基準*}

単位 $(\mathrm{ppm})$

\begin{tabular}{|c|c|c|c|c|c|c|c|c|c|c|c|}
\hline & 河 & & 川 & & 湖 & 沼 & 工 湖） & & 海 & 域 & \\
\hline 類＼cjkstart別 & $\mathrm{pH}$ & BOD & SS & DO & $\mathrm{pH}$ & COD & SS & DO & $\mathrm{pH}$ & $\mathrm{COD}^{* * *}$ & DO \\
\hline A A & $6.5 \sim 8.5$ & 1 & 25 & 7.5 & $6.5 \sim 8.5$ & 1 & 1 & 7.5 & & & \\
\hline $\mathrm{A}$ & $6.5 \sim 8.5$ & 2 & 25 & 7.5 & $6.5 \sim 8.5$ & 3 & 5 & 7.5 & $7.8 \sim 8.3$ & 2 & 7.5 \\
\hline B & $6.5 \sim 8.5$ & 3 & 25 & 5 & $6.5 \sim 8.5$ & 5 & 15 & 5 & $7.8 \sim 8.3$ & 3 & 5 \\
\hline $\mathrm{C}$ & $6.5 \sim 8.5$ & 5 & 50 & 5 & $6.0 \sim 8.5$ & 8 & $* *$ & 2 & $7.0 \sim 8.3$ & 8 & 2 \\
\hline $\mathrm{D}$ & $6.0 \sim 8.5$ & 8 & 100 & 2 & & & & & & & \\
\hline $\mathrm{E}$ & $6.0 \sim 8.5$ & 10 & $* *$ & 2 & & & & & & & \\
\hline
\end{tabular}

* 大腸菌群数は省略

**ごみなどの浮遊が認められないこと

***アルカリ性法

- 1 に各種水質基準からの重金属基準值，およびバッ クグラウンドとしての海水, 地殼中の数值を, 表 1 2 に生活環境基準を示した。また，このような重金属 のポピュラーな分析法として吸光光度法, フレーム光 度法, 原子吸光法の検出限界の比較を表 2 に示した。 なお，代表的な高感度法としてスパークソース質量分 析法と中性子放射化分析法のデータを併示した。この 表では比較のため絶対検出限界で示してあるが，実用 上の定量下限はこの数字の300～500倍であろら。
分析方法選択の 基準として 感度以外に 精度, 正確 さ，簡易性，じん速性などが考慮される。これらを総 合して，水中の重金属定量に適した方法は吸光光度 法, 原子吸光法, ポーラログラフ法であろう。アルカ リ金属, アルカリ土金属にはフレーム光度法も広く用 いられているが，原子吸光法の展開を契機として，そ の適用範囲の挔大を目的とするバーナー, 燃料系など の改良が進められている。フレーム光度法の新しい励 起源としてプラズマ加熱法の展開が期待されている。 


\section{表 2 絶対検出限界}

(単位 $10^{-9} \mathrm{~g}$ )

金 属 吸光光 原子吸フレーム 放射化 スパーク 度法光法光度法分析ソース

$\begin{array}{lrcccl}\mathrm{Hg} & 5 & 20 & 100 & 1 & 0.6 \\ \mathrm{Cd} & 3 & 0.1 & 20 & 5 & 0.3 \\ \mathrm{~Pb} & 6 & 1 & 30 & 10^{3} & 0.5 \\ \mathrm{Cr} & 7 & 0.5 & 0.5 & 100 & 0.05 \\ \mathrm{As} & 10 & 50 & 100 & 0.1 & 0.06 \\ \mathrm{Cu} & 2 & 0.5 & 1 & 0.1 & 0.08 \\ \mathrm{Zn} & 100 & 0.2 & 80 & 10 & 0.1 \\ \mathrm{Mn} & 5 & 0.5 & 0.5 & 50 & 0.05 \\ \mathrm{Fe} & 200 & 1 & 0.3 & 5 \times 10^{3} & 0.05\end{array}$

必要量 $0.1 \mathrm{~m} l \quad 0.1 \mathrm{~m} l \quad 0.1 \mathrm{~m} l$

液層 $1 \mathrm{~cm}$

$4-1-1$ 前処理

水質分析とくに重金属の定量においては有機物，多 量の塩類の除去, あるいは感度増大のための濃縮など がしばしば必要になる。この共通的な問題について考 察してみよう。

1) 濁り

試料中に含まれる固形物の扱いについては統一され た方式はない。その一つの考え方については $3-4$ に 述べたので省略する。

2) 有機物

試料中に存在する有機物の取り扱いはかなり面倒で ある。これらは着色, 吸着, 錯化, 緩衝, 沈殿などさ まざまの形で重金属定量の妨害となりやすい。したが つて, 事前に完全に, または障害を生じない程度に分 解しておくことが必要である。

分解方式は湿式と乾式に大別されるが，成分損失を 避けるためには前者が好ましい。

湿式分解法は a) 硝酸十硫酸, b) 硝酸十過塩素 酸，ｃ）水酸化ナトリウム十過酸化水素，ｄ）硫酸十 過マンガン酸などを目的に応じて使い別ける。水銀な どとくに揮発しやすい成分の場合は還流分解方式をと 万。

乾式分解法では試料を蒸発乾固し, 電気炉で 450 $550^{\circ} \mathrm{C}$ に加熱して有機物を分解する。成分の揮発, あ るいは不溶化を招きやすいので適用はかなり限定され る。低温灰化装置, プラズマアッシャーなどの名称で 市販されている活性化酸素利用による灰化法も有力な 手段である。

\section{3) 蒸発}

共存成分も同時に濃縮されるため障害を生じやす い。原子吸光法の前処理として行ならときは粘性の変 化, 分子吸光, 光散乱などの障害に注意する。

4) 蒸留, 揮散

クロム, ひ素，水銀などはそれぞれ塩化クロミル， アルシン，金属水銀として気化分離できる。

5) イオン交換

重金属成分を一挙に，しかも高度濃縮（数 100 倍に も）できる点に魅力があるが，操作に長時間を要する ことが最大の久点である。定量的交換吸着には $2 \sim 5$ $\mathrm{m} l / \mathrm{min}$ 程度の緩速が望ましいので $l$ オーダーの試料 を処理にするには数時間を要することになる。

陽イオンの単純一せい濃縮には強酸性陽イオン交換 樹脂, 重金属類の選択濃縮にはキレート樹脂 (Dowex A-1, Chelex 100) が用いられる。亜鉛, カドミウ ムの選択交換濃縮に対する $1 \sim 2 \mathrm{~N}$ 塩酸酸性における 強塩基性陰 イオン交換樹脂の利用も有力な方法であ る。

6) 共沈

微量成分の捕集, 濃縮に対して共沈法が用いられて いる。多く用いられるキャリヤーは水酸化鉄 (III), 二酸化マンガン，硫化銅などである。

7) 溶媒抽出

重金属を金属キレートあるいは分子会合錯体の形で 水と混合しない溶媒に抽出するこの方法はもつとも広 く用いられている。

濃縮効果はVaq. /Vorg. の液量比に支配されるが， 抽出百分率，\%Eが次式にしたがつて変化することに 注意しなければならない。

$$
\% E=\frac{100 D}{D+\text { Vaq. /Vorg. }}
$$

ここにDは分配比。したがつてDの小さい抽出系では 両相の液量比を大きくとつても, その割合に濃縮効果 は上らないことになる。

抽出された有機相は, 強く着色している場合はその まま吸光光度法, 溶媒の燃焼性が良好な場合は原子吸 光法の対象となる。あるいは, 適当な水溶液 (一般的 には酸）で金属を逆抽出して水相に移すか, 有機溶媒 を揮散したのち，残留有機物を分解して無機水溶液と し，以降の分析操作を適用する。

抽出系の例は吸光光度法, 原子吸光法 の項で述べ る。

$4-1-2$ 吸光光度法

吸光光度法は各種の標準分析法において重金属イオ 
ンばかりでなく, 陰イオン類に対しても主流の地位を 占めてきた。しかし，少なくとも重金属類に対して は, 感度, 簡便さに扔いて, よりすぐれている原子吸 光法にその座を奪われつつある。新しい試薬の開発, 方法の改良など，毎年多数の報告が発表されている が, 吸光光度法の感度の理論的限界は大体 $10^{-5} \sim 10^{-6}$ $\mathrm{M}$ ，すなわち $n \sim 0 . n \mathrm{ppm}$ と考えられているので飛躍 的な感度の向上は期待できない。この分野で高感度が 期待できるのは, けい光錯体の生成によるけい光光度 法と, 重金属の接触作用を利用する接触分析法である う。とくに, 後者では吸光光度法の数 10 倍 数 100 倍 に達する感度が得られている。

重金属の吸光光度定量の代表的試薬としてジチゾン (ジフェニルチオカルバジン) が挙げられる。これは

$$
\mathrm{S}=\mathrm{C}<\begin{aligned}
& \mathrm{NH}-\mathrm{NH}-\mathrm{C}_{6} \mathrm{H}_{5} \\
& \mathrm{~N}=\mathrm{N}-\mathrm{C}_{6} \mathrm{H}_{5}
\end{aligned}
$$

の構造で, 四塩化炭素, クロロホルム溶液として用い られる。ジチジンと反応し, 定量的抽出ができる元素 を周期表の位置で示す。

\section{Mn Fe Co $\mathrm{Ni} \mathrm{Cu} \mathrm{Zn}$}

Pd Ag Cd In Sn Te $\mathrm{Pt} \mathrm{Au} \mathrm{Hg}$ Tl Pb Bi Po

しかし，錯体生成は $\mathrm{pH}$ の影響を大きくうけるので $\mathrm{pH}$ の調節によつてかなりの選択性が得られる。もつ とも酸性側 $(\mathrm{pH} \sim 1)$ で抽出されるのは $\mathrm{Pd}, \mathrm{Ag}$, $\mathrm{Hg}$ ，これに $\mathrm{Sn}$ (II)， Bi， Cu， $\mathrm{Zn}$ が続き ( $\mathrm{pH} 1$ $5)$, さらに $\mathrm{Pb}, \mathrm{Co}, \mathrm{Ni}, \mathrm{Cd}$ が続く $(\mathrm{pH} 7 \sim 12)$ 。 マスキング剤を併用すると一層の選択性が得られ る。その 1 例を表 3 に示す。

\section{表 3 ジチゾンと反応する金属}

\begin{tabular}{|c|c|c|}
\hline 性 & マスキング郕 & 金 \\
\hline アルカリ性 & $\mathrm{CN}^{-}$ & $\begin{array}{l}\mathrm{Pb}, \mathrm{Sn}(\mathrm{II}), \mathrm{Tl}(\mathrm{I}) \\
\mathrm{Bi}\end{array}$ \\
\hline 微 酸 性 & $\mathrm{CN}^{-}$ & $\mathrm{Pd}, \mathrm{Hg}, \mathrm{Ag}, \mathrm{Cu}$ \\
\hline 希 酸 性 & $\mathrm{SCN}^{-}$ & $\mathrm{Hg}, \mathrm{Au}, \mathrm{Cu}$ \\
\hline 11 & $\mathrm{SCN}+\mathrm{CN}^{-}$ & $\mathrm{Hg}, \mathrm{Cu}$ \\
\hline$\prime \prime$ & $\mathrm{Br}^{-}\left(\right.$または $\left.\mathrm{I}^{-}\right)$ & $\mathrm{Pd}, \mathrm{Au}, \mathrm{Cu}$ \\
\hline $\mathrm{pH} 5$ & $\mathrm{~S}_{2} \mathrm{O}_{3}^{2-}$ & $\mathrm{Pd}, \mathrm{Sn}(\mathrm{II}), \mathrm{Zn}$ \\
\hline $\mathrm{pH} 4 \sim 5$ & $\mathrm{~S}_{2} \mathrm{O}_{3}^{2-}+\mathrm{CN}^{-}$ & Sn (II), Zn \\
\hline $\mathrm{pH} 4.5$ & EDTA & $\mathrm{Au}, \mathrm{Ag}, \mathrm{Hg}$ \\
\hline アルカリ性 & $\begin{array}{l}\text { くえん酸(ま } \\
\text { たは酒石酸) }\end{array}$ & 抽出金属に影響なし \\
\hline
\end{tabular}

工場排水 JIS には $\mathrm{Hg}, \mathrm{Cd}, \mathrm{Pb}, \mathrm{Zn}$ に対してジ チゾン法が用いられている。Cd の場合, 環境基準の $0.01 \mathrm{ppm}$ を正しく求めるには検水 $500 \mathrm{~m} l$ を用い权ば ならない。その他は $50 \sim 100 \mathrm{~m} l$ の液量でよい。

亜鉛はジチゾン法のほかにジンコン法も用いられ る。

クロムはジフェニルカルバジドと $\mathrm{Cr}(\mathrm{Vl})$ の呈色を 利用する。したがつて全クロムの定量ではすべてを 6 価に酸化したのち, 発色定量する。

七素は水酸化鉄共沈法で濃縮分離したのち, アルシ ン, $\mathrm{As}_{3}$ として気化，これをジエチルジチオカルバ ミン酸銀ピリジン溶液に吸収発色させる。または, 同 様共沈濃縮したのち, よう化物としてひ素を抽出し, 最終的にはへテロポリ青として発色, 定量する。

銅は EDTA とくえん酸をマスキング剂として添加 し, ジエチルジチオカルバミン酸錯体として酢酸ブチ ルに抽出する方法が選択性にすぐれている。

マンガンは酸化して過マンガン酸とし, その呈色に よる方法と, より感度の高いホルムアルドキシム法が 用いられている。

鉄は 2 価に還元後, $o$-フェナントロリン錯体とし て吸光光度定量する方法が代表的である。

4-1-3 ポーラログラフ法

重金属の定量に対してポーラログラフ法は感度がや や不足であり, 操作の上でも簡便とはいえないが, 数 成分を同時に定量できることは大きな利点である。

直流ポーラログラフ法の感度は大体 $10^{-4} \sim 10^{-5} \mathrm{M}$ で あり, 多量の前放電物質の存在が以降の定量の障害と なる。交流ポーラログラフ法では感度はやや上昇 ( $\left.10^{-5} \mathrm{M}\right)$ 乙, 前放電物質はほとんど支障なく, ピーク の分離も良好となる。く形波ポーラログラフ法では感

\section{表 4 ポーラログラフ法}

$\begin{array}{cccc}\text { 金 属 } & \begin{array}{c}\text { 半波電位 } \\ 1 \mathrm{~N}\end{array} & \begin{array}{c}\mathrm{V} \text { v s. } \\ 1 \mathrm{M}\end{array} & \begin{array}{c}\text { S.C.E. } \\ 1 \mathrm{M}\end{array} \\ & \mathrm{HCI} & \mathrm{H}_{3} \mathrm{PO}_{4} & \begin{array}{c}\mathrm{NH}_{4} \mathrm{OH}- \\ \mathrm{NH}_{4} \mathrm{Cl}\end{array} \\ \mathrm{Cu} & -0.2 & -0.3 & -0.5 \\ \mathrm{Zn} & & -1.0 & -1.3 \\ \mathrm{~Pb} & -0.44 & -0.40 & \\ \mathrm{Cd} & -0.64 & -0.59 & -0.81 \\ \mathrm{Ni} & & -1.0 & -1.1 \\ \mathrm{Co} & & & -1.3 \\ \mathrm{Bi} & -0.1 & & \\ \mathrm{Sn} & -4.7 & & \end{array}$


度はさらに上昇 $\left(\sim 10^{-7} \mathrm{M}\right)$ するが，かなり微妙な方 法で適用にも制限を生じる。標準法に採用されている ものを表 4 に示する。

この分野では陰極線ポーラログラフィー，陽極溶出 ポーラログラフィーが高感度法として注目される。と く後者は定電位で一定時間電解したのち, 正電位側 に掃引する方法で, 電解が前濃縮の役割を果すことに なるので $10^{-9} \mathrm{M}$ 亿達する感度が得られている。 $\mathrm{ppb}$ るいはそれ以下の $\mathrm{Pb}, \mathrm{Cu}, \mathrm{Zn}, \mathrm{Cd}$ などの定量が報 告されている。

\section{4-1-4 原子吸光法}

原子吸光法が急速に浸透している。これを反映して J I S K 0121 原子吸光分析方法通則が定められ, 目 下改正作業中の J IS K 0102 工場排水試験方法にも $\mathrm{Cu}, \mathrm{Zn}, \mathrm{Pb}, \mathrm{Cd}, \mathrm{Ni}, \mathrm{Co}, \mathrm{Mn}, \mathrm{Fe}, \mathrm{Cr}$ などにこ の方法が適用されようとしている。

ここに対象としている重金属のらち, いろいろの要 因を総合判断して，原子吸光法に適しているものは， $\mathrm{Cd}, \mathrm{Pb}, \mathrm{Cu}, \mathrm{Zn}, \mathrm{Mn}$ ，やや問題があるものは $\mathrm{Fe}$, $\mathrm{Cr}$ そして問題の多いものは $\mathrm{As}, \mathrm{Hg}$ といら分類にな ろら。このらら, Hg はフレームレス原子吸光法の適 用が望ましく, その詳細は後に述べる。

ここで, 各論に入る前に原子吸光法の前処理として の溶媒抽出法について若干述べておきたい。

濃縮は $4-1-1$ 前処理の各項の方法が適用できる が，原子吸光法の場合は溶媒抽出法がもつとも適して いる。すなわち, Vaq./Vorg. と液量比による濃縮之 有機溶媒効果の相乗によつて数10倍の感度上昇が達成 されるからである。この場合, 溶媒には良好な燃燒性 が要求され，酢酸ブチル，酢酸エチル，メチルイソブ チルケトンなどのエステル, ケトン類が多く用いられ る。

原子吸光法における溶媒抽出用の試薬には多数のも のが利用できるが, ジエチルジチオカルバミン酸ナト リウム (DDTC) とピロリジンジチオカルバミン酸 アンモニウム (A P D C) がもつとも広く用いられて いる。いずれも表 5 に示す約 30 の元素と錯体を生成す ることが知られているが，とくに後者は前者の酸性側 で分解する欠点を改良したもので $\mathrm{pH} \sim 2$ 以上で使用 できる。

$$
\begin{gathered}
\text { D D T C : } \left.\begin{array}{l}
\mathrm{H}_{3} \mathrm{C}-\mathrm{H}_{2} \mathrm{C} \\
\mathrm{H}_{3} \mathrm{C}-\mathrm{H}_{2} \mathrm{C}
\end{array}\right\rangle \mathrm{N}-\mathrm{C} \ll \\
\mathrm{S} \\
\text { A P DC } \left.: \begin{array}{l}
\mathrm{S}-\mathrm{Na} \\
\mathrm{H}_{2} \mathrm{C}-\mathrm{H}_{2} \mathrm{C} \\
\mathrm{H}_{2} \mathrm{C}-\mathrm{H}_{2} \mathrm{C}
\end{array}\right\rangle \mathrm{N}-\mathrm{C} \aleph_{\mathrm{S}}^{\mathrm{S}-\mathrm{NH}_{4}}
\end{gathered}
$$

\section{表 5 D D T C，A P D C 錯体}

DDTC :

Ti V Cr Mn Fe Co Ni Cu Zn Ga As Se Mo W

$\mathrm{Pd} \mathrm{Ag}$ Cd In Sn Sb Te W $\mathrm{Au} \mathrm{Hg} \mathrm{Tl} \mathrm{Pb} \mathrm{Bi}$

$\mathrm{U}$

A P DC :

$\mathrm{V}$ Cr Mn Fe Co Ni Cu Zn

As Se Nb Mo Ru Rh Pd Ag Cd Sn Sb Te W Os Ir Pt Au Hg Tl Pb Bi U

原子吸光法の前処理としての溶媒抽出では選択性は あまり要求されないが, 必要あれば $\mathrm{pH} の$ 調節と, 酒 石酸, E D T A, シアン化カリウムなどのマスキング 鼡の添加によつて選択性を付与できる。

ジチゾンは前述のように抽出吸光光度定量試薬とし て用いられているが，抽出後酸で逆抽出して重金属を 水相に戻すか，溶媒を揮散したのち残留するジチゾン 塩を硝酸と過塩素酸で分離し，いずれも水溶液として 原子吸光定量する方法も用いられる。そのほか, ジチ ゾンを常用の四塩化炭素, クロロホルムの代わりに, 燃燒性のよい M I B K, プロピオン酸エチルなどの溶 液として抽出, 直接噴霧する方法も行なわれている。

カドミウムは原子吸光法におけるもつとも感度の高 い元素の一つであるが，環境基準の $0.01 \mathrm{ppm}$ を測る ためには数倍以上の濃縮が必要である。とくに著しい 妨害はないが, 高濃度のハロゲン化アルカリ, カルシ ウム塩などの存在は分子吸収, 光散乱などの障害を生 じるので分離しておくことが望ましい。この場合, 内 部標準法を適用すればこの問題は解消, 軽減される が，適用機種に制限を生じることになる。このほか, 1 -メルカプトベンゾチアゾール, ヨウ化物, 高分子 量アミンなどによる抽出法も用いられている。

亜鉛はカドミウムとほとんど同様の方法で定量でき る。一般に, 悪鉛の存在量はカドミウムよりはるかに 多く, しかも基隻值も高いので水溶液のままで十分な 場合が多い。

鉛, 銅, マンガンの原子吸光法の適用においてとく に問題となる点は少ない。

クロムは還元性のふん囲気, つまり多然料フレーム の感度が高い。しかし，燃料組成による影響が大きい ので, 若干感度は低下するが高温の亜酸化窒素 -アセ チレン系の方が標準法である空気ーアセチレン系より 
も安定で, 問題は少ない。

七素は共鳴線が $1937 \AA$ にあり, この領域ではフレ 一ムによる吸収が大きく, 測定の妨害となる。フレー ムの透明度を高める目的でアルゴン, 窒素の混合が行 なわれている。また, 感度も低いので七素の利用効率 を高める目的でアルシンとして冷却トラップ濃縮する 方法, あるいは, ヒモリブデン酸を定量生成後, モリ ブデンを定量して間接定量する方法などが行なわれて いる。

水銀は原子吸光法の感度がきわめて悪いので, 若干 の濃縮では実用に堪えない。水銀は“貴”金属で容易に 還元されて $\mathrm{Hg}^{0}$ を生じ，または化合物の分解によつて 容易に水銀蒸気を生成する。この利点を生かして, い わゆるフレームレス (flameless) の原子吸光法が急速 に発展してきた。溶液中の微量水銀を銅線や銀線上に アマルガムとして固定, あるいはジチゾン塩として分 離する。前者の場合は電熱, 後者では加熱分解によつ て発生する水銀蒸気を石英製の吸収セルに導き, 吸光 を測定する。溶液の直接還元では, 通常, 酸性溶度液 にすず（II）を加えて $\mathrm{Hg}^{2+}$ を $\mathrm{Hg}^{0}$ に還元し，溶液通 気によつて $\mathrm{Hg}^{0}$ を気相に駆い出し, これを吸収セルに 導いて定量する。循環通気法と, 単純吸引法が示され ている。筆者らは多量の塩化ナトリウムの存在下, 酸 性溶液のすず（II）還元で無機水銀を，アルカリ性溶 液, 微量銅（II）の存在下のすず（II）還元で無機十 有機 (塩化メチルー, 塩化エチル -, 酶酸フェニル水 銀）水銀を定量する方法を示した。

いずれの方法でも ppbあるいはそれ以下の水銀をじ 几速, 正確に定量できる。この方法は前述の J IS K 0102-1971に採用予定であり，またこの原理に基づく 専用器や付属装置が市販されている。

4-1-5 その他の方法

以上に代表的な方法について概略を記述したが, 最 後にアルキル水銀の定量法について略述しておこう。

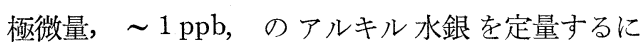
は, 現在のところごく限られた方法しかない。環境測 定にはガスクロマトグラフ法と薄層クロマトグラフ分 離 -ジチゾン 吸光光度法が規定されている。前者で は, アルキル水銀を塩酸溶液からベンゼンに抽出, 精 製操作を経てその一定量をGLC カラムに注入, 電子 捕獲型検出器で検出, 定量する。別の一部についてグ ルタチオン処理によるピーク消失をチェックし，アル キル水銀の存在を確認する。

TL C 法では, ベンゼン抽出物をシリカゲル薄層板 にスポットし, これを展開, アルキル水銀の $R_{f}$ 值に
相当する部分を削りとり, 酸浸出後ジチゾン吸光光度 法で定量するか, 削りとつた部分を加熱し, 発生する 水銀蒸気による吸収を測定, 定量する。

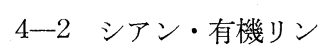

シアン・有機リンは人の健康に重大な影響をおよぼ すものとして表 1 - 1 に示したように $\mathrm{Cd}, \mathrm{Hg}$ など の重金属類と同様に全国一律の基隻值が定められてい る。

水溶液中のシアンは酸と反応して容易にシアン化水 素を発生する $\mathrm{CN}^{-}$として存在するほか, 各種の金属 錯イオンとして存在している。金属錯イオンは安定度 の順に $\left[\mathrm{Fe}(\mathrm{CN})_{6}\right]^{3-}>\left[\mathrm{Hg}(\mathrm{CN})_{4}\right]^{2-}>\left[\mathrm{Fe}(\mathrm{CN})_{6}\right]$ ${ }^{4-}>\left[\mathrm{Cu}(\mathrm{CN})_{4}\right]^{2-}>\left[\mathrm{Cd}(\mathrm{CN})_{4}\right]^{2-}>\left[\mathrm{Zn}(\mathrm{CN})_{4}\right]^{2-}$ と なり, いわゆる全シアン, 遊離シアンの定義のあいま いさの原因となつている。シアン化合物の毒性は $\mathrm{CN}^{-}$ の放出しやすさと平行関係にあるから, 安定度の大き いものほど毒性は低いことになる。この間の事情の複 雑さが, いわゆる遊離シアン, 全シアンの定義をあい まいなものにしている。

環境基準におけるシアンは全シアン, すなわち $\mathrm{pH}$ 2 で蒸留し, 留出してくる $\mathrm{HCN}$ をアルカリに捕集 し, チオシアン酸水銀法で吸光光度定量し, これで検 出されてはならないことになつている。この蒸留条件 では $\mathrm{CN}^{-}$はもちろん, 安定度の低、带鉛, カドミウ ムなどの錯イオンからは HCN を発生するが, 安定度 の高いフェリ，フェロシアン錯イオンや銅シアン錯イ オンからの $\mathrm{HCN}$ の発生はその一部にすぎない。した がつてシアンがこのような形で存在するときは “全シ アン”が定量されている訳ではないことになる。

また，“遊離シアン”の定量法として pH 5.0 の試 料汇通気, あるいは $\mathrm{pH} 5.5$ で蒸留を行ない発生する $\mathrm{HCN}$ を捕集する方法があるが，この場合も定量され るのは $\mathrm{CN}^{-}$の全部と安定度の低い金属シアン錯イオ ンの一部ということになる。

捕集した $\mathrm{HCN}$ はアルカリ溶液中では $\mathrm{CN}^{-}$を生じ て抒り, これにチオシアン酸第二水銀を加えると,

$2 \mathrm{C} \mathrm{N}^{-}+\mathrm{Hg}(\mathrm{SCN})_{2} \rightarrow \mathrm{Hg}(\mathrm{CN})_{2}+2 \mathrm{~S} \mathrm{C} \mathrm{N}^{-}$, の反応を生じる。溶液に $\mathrm{Fe}^{3+}$ を加えるとチオシアン 酸鉄の赤色を呈し, 光度定量が可能になる。しかし, $\mathrm{Cl}^{-}$その他八ログン類は全く同様の反応を呈し, 発色 するので正の誤差を与えることになるので海水試料な ぞのように多量のハロゲンを含む場合には再蒸留など の手段を構じなければならない。この方法の定量下限 は0.3 0. 1ppm であるから0. 5ppm 以下の定量では, より高感度なピリジンーピラゾロン法の適用が好まし 
く，選択性もまた，この方がすぐれている。

有機りんとして環境基準に定めているのは毒性の強 いパラチオン, メチルパラチオン（以上，現在製造中 止), $\mathrm{EPN}(o-$ エチルーo- $(p-$ ニトロフェニル) フ ェニルホスホノチオレート), およびメチルジメトン である。前三者はいずれも $p$-ニトロフェニル基を含 んでいるので同一方式で定量できる。すなおち, 有機 りんを $n$-ヘキサンで抽出し, クロマトグラフ分離し たのちアベレルーノリス法（有機りん化合物を還元， 曲硝酸でジアゾ化し $\alpha$-ナフチルエチレンジアミンと カップリングさせて呈色) または $p$ - ニトロフェノ 一ル法 (有機りんをアルカリで加水分解し, 生成する $p$-ニトロフェノキシドの黄色を測定）で定量するの である。

一方, メチルジメトンはクロロホルム抽出後, 薄層 クロマトグラフ分離する。顕色後, メチルジメトンの スポットを集め, メタノールで抽出する。これを過塩 素酸と硫酸で分解し，モリブデン青吸光光度法による りんの定量が指定されている。

このほか, JISには有機リンとして $\operatorname{EDDP}(o-エ$ チル $S, S-$ ジフェニルホスホロジチオレート) のガ スクロマトグラフ法, 薄層クロマトグラフガスクロマ トグラフ法が予定されている。

$4-3$ 共通項目

水質污濁の評洒に対して広く用いられている項目は $\mathrm{pH}, \mathrm{BOD}, \mathrm{COD}, \mathrm{SS}, \mathrm{DO}$ などである。このらち $\mathrm{pH}$ はガラス電極による測定法が確立しており，ほと ルど問題はない。

4-3-1 BOD, DO, COD, TOC

B O D \&生物化学的酸素要求量で「水中の微生物の 増殖あるいは呼吸作用によつて消費される溶存酸素 量」と定義され，水の有機性污濁を示す指標として広 く用いられている。換言すれば, 水中の有機污濁質が 微生物の作用によつて酸化, 安定化されるために消費 される酸素量であり，污濁の著しいものほど，高い BOD を示すことになる。

B O D の測定は試料を適宜希釈 (緩衝, 栄養塩の添 加をかねて）し，要すれば殖種を行ない，予想される B O D 值をはさんで希釈系列を調製する。これを $20^{\circ}$ C，5日間静置する。この前後における溶存酸素量を 測定し, その減少量に希釈倍率を乗じて BOD を求め る。溶存酸素量の測定はウィンクラーアジ化ナトリウ ム変法 (硫酸マンガン溶液およびアルカリ性よう化力 リウムーアジ化ナトリウム溶液を加えて生じる水酸化 第一マンガンが溶存酸素によつて水酸化第二マンガン
となる。これに硫酸を加え, 酸性にすると溶存酸素量 に対応するよう素を遊離するので, これをチオ硫酸ナ トリウム溶液で滴定する）が標準法として用いられる ほかミラー変法 (メチレンブルーを指示薬とする硫酸 第一鉄滴定)，あるいは D O 計による簡易測定法も利 用されている。

標準法による BOD測定は繁雑でもあり, また長時 間を要するので各種自動測定器の開発が行なわれてい る。すなわち, 密閉器中での酸素の減少に伴ら気圧変 化, あるいは減少した酸素をクーロメトリーで補給 し, これに要する電気量, メチレンブルー脱色などの パラメーターが利用されている。

BOD と DO は逆比例の関係にあり, 一般にきわめ て清浄な水ではBOD は $1 \mathrm{ppm}$ 以下, DOは 7 8 ppm, 污染されていない川（とくに下水により）ではBOD 4 ppm以下，臭気を発する程度の污染では BOD は 10 ppm以上, DO は $2 \mathrm{ppm}$ 以下である。

このようにDO も污濁指標として重要であり, その 測定は上述の化学的方法のほか選択酸素透過膜を利用 するガルバニセル方式あるいはポーラログラフ方式の DO 計が広く用いられている。

C OD化学的酸素消費量で「溶液中の被酸化物 質, 主として有機物によつて消費される酸素量」と定 義される。CODは酸化剤, 反応条件などの異なる多 数の方法が使用され，一時はきわめて混乱していた が，現在ではかなり整理されてきている。

C O D 測定には試料に一定過剩量の酸化剂を加え て, ある反応条件下に一定時間保つたのち, 残留して いる酸化剤の量を定量する方法が用いられている。酸 化剂は過マンガン酸カリウムと重クロム酸カリウムの 二つに大別されるが，わが国の方法は前者によつてい る。とくに, JIS (排水) では $100^{\circ} \mathrm{C}$ (30分) 過マン ガン酸カリウム法をCODと呼ぶことにして混乱を避 けている。この硫酸酸性, $100^{\circ} \mathrm{C}$ 過マンガン酸カリウ ム法の問題点である $\mathrm{Cl}^{-}$による妨害は硫酸銀粉末添加 によって $\mathrm{Cl}^{-} を \mathrm{Ag} \mathrm{Cl}$ として固定することにより回 避できる。C O D 自動定量に対しては過剩の過マン

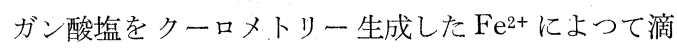
定する方式が開発されている。

一般にCODとBODの間には相関が成立するが， その係数は一定していない。さきに述べたように BO D測定はかなり面倒であり, 測定精度もよくないが, 生物の自浄作用との関連に㧍いて棄て難いものがあ り,一方, CODは測定条件を定めておけば, じん速 に再現性のよいデータを得ることができる。しかも， 
過去の，それぞれの蓄積データの取扱いとの関連もあ つて, このような事情が方法の整理, 統一に対するブ レーキとなつている。

以上に述べたように，BOD，COD はいずれも反 応の過渡的な点を抑えているにすぎないので, その本 質的な意味づけは困難である。したがつて, より本質 的な指標としてUOD (Ultimate Oxygen Demand, 最終酸素消費量)の測定が志向されている。たとえ ば, T O C (全有機炭素) はその合理性の点では B O D，CODにはるかに優るものであり，いくつかの測 定方式が提案されている。もつとも簡単なのは少量の 試料を加熱, 燃焼させ, 生成 $\mathrm{CO}_{2}$ を非分散赤外法で 定量する方法である。

\section{4-3-2 S S}

S S (Suspended Solids) すなわち䀣濁物質とは粒 径 $2 \mathrm{~mm}$ 以下の水に不溶の小粒子をいう。この測定に は, ガラスろ過器法, ブフナー漏斗法, グーチるつぼ 法, 遠心分離法, 蒸発残留物差法などが定められてい るが，いずれも手分析であるため，かなり厄介であ る。これらのうち, ガラスろ過器法, ブフナー漏斗法 ではろ紙が用いられているが，これに代わる耐熱均質 ろ紙としてガラスファイバーフィルター, あるい均 質ろ紙としてメンブランフィルター類の活用も検討さ れている。

法的な規制はほとんど S S で行なわれているが，上 述のよらにその測定はかなり厄介なので, 簡易測定法 として濁度計が利用されている。測定方式は光散乱 (チンダル光), 表面乱反射, 積分球式などがあるが, 後二者溶液の着色による影響が少ない。

このほか, ガラスシリンダーの底面の文字, 記号を 識別できる限界の水層の梁さを $\mathrm{cm}$ で表示する透視度 法も野外におけるSSの簡易測定法として有用であ る。白濁懸濁液においては濁度と透視度の間には, お のおのの対数間に直線関倸が知られている。

4-3-3 n-ヘキサン抽出物質（油分）

$n$-ヘキサン抽出物質, 一般に油分と称される水質 項目は主として石油系污濁の指標として用いられてい る。この成分は水と混合しにくい特性があるので, サ ンプリングには特別の配慮が必要であり, これについ ては 3-2 に述べた。

この測定方法では試料から $n$-ヘキサン可溶物を抽 出し, 有機溶媒を揮散させたのち残留物の重量を測定 することになつている。したがつて，その過程で軽質 油の損失が必然的に生じる。試料を $1 l$ 程度使用する 場合は, 風袋との関連もあつて定量下限は約 $5 \mathrm{ppm}$ と
考えられる。一方, 測定下限の要求は各種規制におけ る $1 \sim 0 . n \mathrm{ppm}$ ，あるいは異臭魚発生の限界值として $0.01 \mathrm{ppm}$ といつた值まで示されているので, できれば $0.1 \mathrm{ppm}$ を測定できる方法が望まれる。しかし，重量 法による限りは定量下限を下げるためには試料量を増 すほかはない。そこで, 試料を最大 $10 l$ まで使用し, 機械かんはん, 亦るいは水酸化鉄生成による微量油分 の捕集操作を加えて $0.1 \mathrm{ppm}$ まで定量できる方法が提 案されている。

一方, 機器的方法で法分散濁度法と赤外吸收法が注 目される。前者は検水に界面活性剂を加えて高速かき まぜにより乳化，その濁度を積分球濁度計で測定する 方法で， $0.5 \sim 100 \mathrm{ppm}$ の油分を測定している。後者 は油分を四塩化炭素に抽出，3.4 3.5 $\mu$ の C - H 伸縮 による吸収を非分散赤外分析計で測定する。定量下限 は $0.1 \sim 0.5 \mathrm{ppm}$ とされている。

このほか, 活性炭濃縮法, ガスクロマトグラフ法, 薄層クロマトグラフ法, 赤外吸収, 質量分析などの方 法のいろいろの組合わせが検討されている。

\section{4-3-4 無機陰イオン類}

無機陰イオン類のうちシアンについてはさきに述べ たが, そのほか $\mathrm{F}-$, $\mathrm{NO}_{2}^{-}, \mathrm{NO}_{3}^{-},\left(\mathrm{NH}_{4}{ }^{+}\right), \mathrm{Cl}^{-}, \mathrm{P}$ $\mathrm{O}_{4}^{3-}, \mathrm{S}^{2-}, \mathrm{SO}_{3}^{2-}, \mathrm{SO}_{4}^{2-}$ などが対象として挙げられ る。その多くは吸光光度法によつて定量されている が, 最近この分野にイオン選択電極が普及しはじめて いる。もちろん, 陽イオン類に対しても数種の電極が 発表されてはいるが， F- $\mathrm{CN}^{-}$などを対象とする研 究が多く見られる。

電極の感応素子は難溶性金属塩の加圧成形 $\left(\mathrm{CN}^{-}\right.$, 八ロゲン, $\mathrm{S}^{2}$-用), ドープした難溶性金属塩単結晶 (F一用)，ガラス薄膜 (アルカリ金属用) などである。 全体的にみて, イオン強度, 共存イオン, 残留効果な どに問題が残されている。しかし, 非常に簡便に測定 できるので工程管理の分野などでは大いに活用できる であろう。

\section{$4-4$ 測定機器}

水質測定に利用される機器は種類が多く, その一部 については随時説明してきたが, その他のものについ て略述する。

電気伝導度計 イオン総量についての情報が得ら れるので, 水質計のような名称でも市販されている。

pH 計ガラス電極方式がほとんどである。精密 級から携带用の簡易型まで多くの機種があり, デジタ ル型も普及してきた。

酸化還元電位計 酸化還元電位は排水処理の管理 
指標として用いられることが多い。

光度計通常の分光光度計のほかに, 混濁試料や 微少吸光度の測定に有力な 2 波長分光光度計, あるい は完全自動光度定量を可能にするオートアナライザー が注目される。

モニター計器類 各種の水質モニター計器類が市 販されているが，その多くは測定エレメントとして水 温, P H, 電気伝導度, 濁度, DOなどを組込んでい る。このほか, イオン選択電極の使用により $\mathrm{Na}^{+}$, $\mathrm{NO}_{3}{ }^{-}, \mathrm{Cl}^{-}$その他の 測定を可能にしたものもあり, 装置の保守の面でも多くの配慮が払われている。

\section{5. 污 濁 評 価}

従来, 水質污溜の評価, 規制は水質基準の数值に みられるよらに污濁質濃度の面からだけ行なわれてき た。したがつて，極端な場合，排水を単に希釈するだ けでも基準值内に納めることが可能な場合もあり, 現 に排水処理工程の終末段階では泠却水, 雑用水などに よる希釈が行なわれている。しかし，これはあくまで 止むを得ざる処置であつて，環境污染への奇与を考え た場合，全く意味をなさないものであることは自明で あろう。環境污染への寄与は, 排出の絶対量によつて 定まるものであり，排水を放流するに当たつて汢常に 排水量と濃度についての考慮を意つてはならない。す なわち, 水質污濁の評価は濃度 $\times$ 流量＝負荷量によつ て行なわれるのが妥当で，たとえ法的な規制はなくて も排水処理計画にはこの概念を組入れておかねばなら ない。

\section{5-1 流量測定}

排水の放流, あるいは河川污濁調查においては流量 測定が必要になるので, その代表的なものについて述 ベる。

\section{5-1-1 容器による測定}

容量既知の容器, たとえばポリバケッ（数 $l \sim 100$ $l)$, ドラムかん $(180 l)$ などを水路の落差のある位 置におき, 満水に要する時間をストップウオッチで測 る。満水に要する時間が 10 秒以上になるような大きさ の容器が望ましい。水槽の表面積を求め, 水位上昇時 間を測定して流量を求めることもできる。

\section{5 - 1-2 流速計による測定}

河川, 水路の直流部を選び, 流れに対して直角に口 ープを固定する。この横断線を等間隔に区分し, 各点 に拉ける深度を測定して河川断面を求めると同時に, 各区間を台形近似で面積計算する。
流速計は鉛直軸に回転子と取り付けたプライス式と 水平軸にとりつけたスクリュ一式があり，流速範囲， 測定方式の異なるいくつかの機種がある。測定は数回 転ごとに音を発する電音式と, 直読式に大別される。

測深線上の平均流速を求め, さらに区間平均流速を 計算し，さきに求めた区間面積にこれを乘ずると区間 流速が得られ，これを合わせて流量とする。

5-1-3 浮子による測定

流速計が使用できない浅い水路などに適用する。波

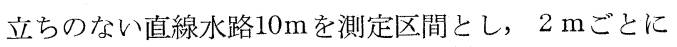
断面を測定し, 平均断面を計算する。軽い表面浮子が $10 \mathrm{~m}$ 区間を通過するに要する時間を数回実測し, 平均 を求める。この数值から得た表面最大流速に0.75を乗 じて平均流速とする。平均流速と断面の積から流量を 求める。

\section{5-1-4 せきによる測定}

水路に正確な仕様にしたがつて恒久的なせきを作 り，水頭を実測して計算式，換算表から 流量を求め る。排水などの流量測定にはもつとも適した方法であ る。直角三角せき, 四角せきなどが多く用いられてい る。

\section{5-1-5 その他の方法}

水路に濃度のわかつたトレーサ一溶液（フルオレッ セン, ローダミンBなど)を流し, しゅうぶんに混合 したで流、濃度を測定し, 計算から流量を求めるトレ 一サー法は谷川などでは便利な方法である。

そのほか, 超音波法, 移動幕法なども知られてい 吕。

なお，大河川の流量測定は長時間を要し，伦険も伴 らので, 河川管理機関の水位-流量曲線やダム放水デ 一タの利用，あるいは主要河川であれば “流量年表” の統計学的利用も考えられてよいであろう。

なお, 河川調查では以上の諸方式で求めた流量デー 夕を水系全体にわたつて検討し, 確からしい值を推定 しながら流量バランスを求める。これに各地点の污濁 質濃度を乗じて負荷量分布を求めると水系の污濁の状 況, 各污染源の寄与率が明白に示されることになる。

\section{6.おわりに}

水質污濁の測定方法およびこれに関連して試料採 取, 流量測定などについて概説した。各項目のバラン スに適切さを欠き，また独断に楩つた記述も多いこと と思われるが, 御指摘頂ければ幸甚これに過ぎるもの はない。また，文献は紙面の都合で 割愛させて頂い た。 


\title{
Measurement of Water Pollutants
}

\author{
by Yoshimi Umezaki
}

(National Research Institute for Pollution and Resorces)

SYNOPSIS : - The present state and future aspect on the measurement of water pollutants and related matters were discussed.

Includings are :

1. introduction.

2. test items and water quality criteria.

3. sampling.

4. test methods including heavy metals (pretreatments, spectrophotometry, polarography, and atomic absorption spectrometry), cyanide, organic phosphorus compounds, oxygen demands (BOD, COD. etc.), dissolved oxygen, suspended solids, oily matters, and instrumentation.

5. Evaluation of pollution. 